\title{
User Satisfaction and Preference for Activation of Ecological Playgrounds
}

\author{
In-Hoi Lee', Hyun-Kyung Kang ${ }^{2}$, and Seung-Jun Back ${ }^{1}$ \\ ${ }^{1}$ Department of Environmental Landscape Architecture, Graduate school, Sangmyung University, Cheonan 31066, South Korea \\ ${ }^{2}$ Department of Environmental Landscape Architecture, Sangmyung University, Cheonan 31066, South Korea
}

\begin{abstract}
This study was conducted to suggest more effective ways to create successful ecological playgrounds. For this study, current status of ecological playgrounds, users' satisfaction and preference were analyzed in July, 2016. A case study was done at Yangpyeong ecological playground, Umyeonsan ecological playground, and Gulponuri ecological playground. To detect current status, location suitability, naturality, eco-education playfulness, and rest·community were examined. Also, It examined users' satisfaction by accessibility, rest·community facility and preference with programs. As a result, planting rate of native species compared to total species did not exceed maximum $45 \%$. Distribution of educational guidance facilities compared to nature experience and play facilities was at least $62.5 \%$. As a result of analyzing satisfaction and preferences on selected sites, users generally had above average level of satisfaction on a 5-point scale. By contrast, the satisfaction on rest facilities, including pergolas and benches was lower. So complementarity of rest and community was required. In case of preference about additional programs at ecological playgrounds, the average preference of taste focused programs was the lowest among programs focusing five senses. Hence, to boost participation and maximize effectiveness of ecological experience, more sensory educational programs should be considered, such as forest observation, smelling flowers focused on olfactory sense, and listening to sounds in forest focused on auditory sense. In additional facilities preference, users most wanted to supplement and add play rides, pergolas and benches. Users wanted to expand rest spaces and experience learning center on a similar level at every single selected site. This study focused on current status analysis of ecological playgrounds in the targeted places, satisfaction of users and preference survey. With ecological resource utilization program plans considering communities, corporations, and environment, it would be able to contribute to bigger creation effects.
\end{abstract}

Keywords: ecological resource utilization program, experience learning center, forest observation, native species

\section{Introduction}

To prevent damage and devastation of the natural environment in Korean territory, South Korea has carried out the Ecosystem Conservation Fund Return Project since the 2000s to make efforts to restore the damaged ecosystem. In particular, an ecosystem conservation cooperation charge is collected from business operators that have a remarkable impact on the natural environment or ecosystem, or bring reduction to biodiversity, thereby supporting ecosystem

This study was funded by the 2016 research fund of Sangmyung University.

Received: January 12, 2018, Revised: January 25, 2018, Accepted: January 26, 2018

First author: In-Hoi Lee, E-mail: 743481@naver.com, ORCID: 0000-0001-5076-0532

*Comresponding author: Hyun-Kyung Kang, E-mail: hkkang@smu.ac.kr, ORCID: 0000-0002-3736-820X 
conservation and regeneration projects that include creation of natural alternatives and restoration of the ecosystem. Recently, as the interest and demand for ecosystem services and ecological welfare increased, government departments are carrying out various projects to conserve, restore and utilize ecological resources, categorized into ecological parks, forest kindergartens, natural yards, ecological playgrounds, and urban microsites.

In particular, ecological playground 'I-tteurak' (children's garden) was built to provide a playground of nature for urban children and an ecological rest area for citizens (Kim, 2016b). This is the Ministry of Environment's project to create ecological playgrounds as part of 'expansion of ecological rest space' as a detailed task of the new government's major government project 'creation of space for happy life and culture' to improve ecological soundness in the city. 'I-tteurak,' the name of the Ministry of Environment's project that served as a bridgehead for bringing nature into the city means children playing joyfully in natural space. It is defined as a natural and ecological space built for play, ecological learning/experience and rest using various natural elements and materials such as soil, water, grass, trees, animals and plants so that children in the city can encounter natural ecology with their parents near their homes. 'I-tteurak' aims to facilitate water circulation, alleviate the phenomenon of heat island, improve urban ecological soundness by expanding green spaces through plantation, cultivate emotions of children through direct experience, play using ecological resources, and develop sensitivity and creativity. In addition, it also aims to serve as a space for healing, relaxing and an ecological community for family-unit urban dwellers and local residents in addition to children (Ministry of Environment, 2014b).

Ecological playgrounds have been built since 2014 Thus, related researches are insufficient. Yet Kim (2016a) recently emphasized the importance of location, natural habitat, eco-friendly materials and programs stimulating the five senses as prior factors for ecological playgrounds. Park (2016) decided that there is high correlation between the formation method and operation status of ecological playgrounds, and presented the current status of ecological playgrounds by categorizing it into direct operation, participatory operation, and non-operation. In most cases there were no separate operation programs, and thus the expansion of participatory operation by private or environmental organizations was suggested as a means to promote ecological playgrounds. There have been many other studies about the concept of building ecological parks and suitable composition by space (Lee, 2008; Park, 2004), and about conservation and restoration of ecological parks, application plans, and ecological education and experience programs (Ku, 2011; Bang and Lee, 2008; Cho, 2011).

As a research trend about ecological observation and experience-centered forest kindergarten programs, Kang (2011) emphasized the importance of education using ecological resources in nature rather than artificial facilities in seasonal nature learning programs. Moreover, some studies proposed forest kindergartens for periodical experience to provide family experiences and learning along with effects of play using ecological resources in forest kindergartens on children (Kim, 2010), as well as daily forest kindergartens based on programs of free play using ecological resources (Lee, 2010). Studies on the concept, formation and programs of ecological parks or forest kindergartens have been actively conducted, but researches on the satisfaction of children or residents that are users of such ecological playgrounds after building them are not sufficient. The biggest advantage of this project is to provide direct experience of natural space within the city. The experience of touching and observing wild animals and plants, dipping feet into the stream, and watching trees change with the seasons provide healing and nostalgia for adults, and exert the effect of building personality and educating children through ecological experience and play. It is currently in the initial stage and thus requires detailed review of guidelines and evaluation of user demands after use.

Therefore, this study would select study areas for each type of ecological playgrounds built thus far, examine the current status, and conduct a preference and satisfaction survey among users, thereby providing baseline data for plans to vitalize ecological playgrounds. 


\section{Research Method}

\section{Research scope}

The study areas are categorized by the location environment that sufficiently reflected the ecological conditions or features nearby, and ecological playgrounds are categorized into three types such as urban life, forest adjacent, and waterside (Ministry of Environment, 2014b). The urban life type is located inside the city and is mostly flatland surrounded by buildings such as dwellings. Artificial structures or facilities are installed or forming impervious areas, and it is isolated from the surrounding ecosystem. The forest adjacent type is located on the outskirts of the city and the boundaries of the city and forest, with hilly areas of natural soil and natural vegetation. The waterside type is located in various places such as the heart of the city or outskirts, with water resources such as rivers, waterways and wetlands or can bring in adjacent water resources. This study selected ecological playgrounds already built and used among the three types based on the Ministry of Environment's guidelines, considering the type, location and features with focus on areas near the densely populated capital regions, areas where various experience/education/play programs are planned and applied, and areas that can use ecological resources with ecological features.

The study areas are Yangpyeong ecological playground in the urban life type located in Yangpyeong-dong, Yeongdeungpo-gu, Seoul; Umyeonsan ecological playground in the forest adjacent type located in Umyeon-dong, Seocho-gu, Seoul; and Gulponuri ecological playground in the waterside type located in Gansan-dong, Bupyeong-gu, Incheon. To determine the features of the study areas in more detail, the current status was examined and a survey was conducted among park users.

\section{Research method}

Based on the survey and analysis of 'Ecological Playground Formation Guidelines' by the Ministry of Environment (2014a), the investigation of the current status is restructured into 4 components such as location suitability, naturality, eco-education/playfulness, and rest/community, and 15 investigation items more specifically (Table 1). First, location suitability is classified into accessibility and land use status. Second, naturality is classified into green area, planting rate of naturalized species, pervious pavement ratio, and impervious pavement ratio. Third, eco-education/playfulness is classified into standardized experience facilities, non-standardized experience facilities, natural geomorphology use, eco-friendly material playground equipment, guidance facilities, distribution ratio of education guidance facility, and distribution ratio of ecological learning space. Fourth, rest/community is classified into resting space area and rest facilities (pergolas, parasol-type shades, benches, drinking fountains).

Table 1. Investigating items of research site.

\begin{tabular}{|c|c|}
\hline Distinction & Investigation Items \\
\hline Locational suitability & - Accessibility (education institution, residential area, transportation), Landuse status \\
\hline Naturality & - Green area, Planting rate of naturalized species, Pervious pavement ratio, Impervious pavement ratio \\
\hline Eco-education playfulness & $\begin{array}{l}\text { - Standardized experience facilities, Non-standardized experience facilities, Natural geomorphology use, } \\
\text { Eco-friendly material playthings, Guidance facilities, Distribution ratio of education guidance facility, } \\
\text { Distribution ratio of ecological learning space }\end{array}$ \\
\hline Rest $\cdot$ community & - Resting space area, Rest facilities (pergolas, parasol-typed shades, benches, drinking fountains) \\
\hline
\end{tabular}

* Ministry of Environment (2014a) 'Reconstruction of ecological playground guidelines' 
Table 2. Contents of questionnaire.

\begin{tabular}{|c|c|}
\hline Distinction & Investigation Items \\
\hline General feature & - Gender, Age, Education, Job, Marriage and parental status \\
\hline Utilization feature & - Recognition, Frequency of use, Activities, Usage group \\
\hline Utilization satisfaction & - Accessibility, Usage effect, Ecological trails, Green space, Planting rate of naturalized species \\
\hline $\begin{array}{l}\text { Rest } \cdot \text { community facility } \\
\text { satisfaction }\end{array}$ & $\begin{array}{l}\text { - Natural permeability, Safety facilities, Subsidiary facilities (toilets, drinking foundations, trash can), } \\
\text { Guidance status (information sign), Rest facilities (pergolas, benches) }\end{array}$ \\
\hline Program preference & - Program type according to the five senses \\
\hline $\begin{array}{l}\text { Eco-education } \cdot \text { playfulness } \\
\text { facility preference }\end{array}$ & - Plaything, Rest space, Experience learning space, Addition and improvements of facilities \\
\hline
\end{tabular}

The survey was conducted on general features, utilization features, satisfaction and preference of users. General features consisted of gender, age, education, job, residential area, and user type (marital and parental status). Utilization features were categorized into recognition of ecological playgrounds, frequency of use, activities, and user group. Satisfaction with accessibility and naturality was classified into accessibility, usage effect, ecological trails, natural awareness and type of plantations. Satisfaction with rest/community facilities was classified into natural permeability, safety facilities, subsidiary facilities (toilets, drinking fountains, trash cans), guidance status (information signs), and rest facilities (pergolas, benches). Program preference consisted of program types according to the five senses. Preference of eco-education/playfulness facilities consisted of playground equipment, rest space, experience and learning space, and addition and improvement of facilities (Table 2). Total 150 copies of the questionnaire were distributed for the survey, and 145 copies were used as valid samples excluding 5 copies with insincere responses. The survey was based on a 5-point Likert scale, and the results were used in the frequency analysis and one-way ANOVA to determine the difference in user satisfaction among ecological playgrounds, using statistical analysis program SPSS 12.0. This study was intended to present ways to vitalize ecological playgrounds by determining user satisfaction and preference of ecological playgrounds based on the current status and user survey.

\section{Results and Discussions}

\section{General status of study areas}

Yangpyeong ecological playground is an urban life type located in Yangpyeong-dong, Yeongdeungpo-gu, Seoul. It had been an artificial and obsolete playground built in 1996, but was newly formed in 2016 with the total area of 2,845 $\mathrm{m}^{2}$, facilities area of $911 \mathrm{~m}^{2}(32 \%)$, and green area of $1,934 \mathrm{~m}^{2}(68 \%)$. Facilities consist of forest maze, combination table and stepping-stone net. Umyeonsan ecological playground is located in 71 Umyeon-dong, Seocho-gu, Seoul and connected to a hiking trail. It had been a neglected and obsolete playground but was newly formed in 2015 with the total area of 4,927.7 $\mathrm{m}^{2}$, facilities area of 1,687 $\mathrm{m}^{2}(34 \%)$, and green area of 3,240 $\mathrm{m}^{2}(66 \%)$. Facilities consist of combination table, log stepping stones, and rocking swing. Gulponuri ecological playground that is a waterside type is located in 403 Galsan-dong, Bupyeong-gu, Incheon. It was newly formed in 2015 on an idle land of a retarding basin with the total area of $12,600 \mathrm{~m}^{2}$ and a small facilities area of $461 \mathrm{~m}^{2}(4 \%)$. The space to use ecological resources including green area is $12,139 \mathrm{~m}^{2}(96 \%)$, with natural space including green area and wetlands taking up most of the space. More specifically, it is divided into open space, adventure space, natural space, and play space, with education-focused facilities such as boreal digging frog habitat, spider play, and insect hotel (Table 3). 
Table 3. General status of research site.

\begin{tabular}{|c|c|c|c|}
\hline Distinction & Yangpyeong & Umyeonsan & Gulponuri \\
\hline Location & $\begin{array}{l}\text { 301-7 Yangpyeong-dong 4-ga, } \\
\text { Yeongdeungpo-gu, Seoul, Korea }\end{array}$ & $\begin{array}{l}71 \text { Umyeon-dong, Seocho-gu, } \\
\text { Seoul, Korea }\end{array}$ & $\begin{array}{l}403 \text { Galsan-dong, Bupyeong-gu, } \\
\text { Incheon, Korea }\end{array}$ \\
\hline Year of establishment & 2016 & 2015 & 2015 \\
\hline Playground area & $2,845 \mathrm{~m}^{2}$ & $4,927.7 \mathrm{~m}^{2}$ & $12,600 \mathrm{~m}^{2}$ \\
\hline Facilities area & $911 \mathrm{~m}^{2}(32 \%)$ & $1,687 \mathrm{~m}^{2}(34 \%)$ & $461 \mathrm{~m}^{2}(4 \%)$ \\
\hline Green area & $1,934 \mathrm{~m}^{2}(68 \%)$ & $3,240 \mathrm{~m}^{2}(66 \%)$ & $12,139 \mathrm{~m}^{2}(96 \%)$ \\
\hline $\begin{array}{l}\text { Current status of } \\
\text { facilities }\end{array}$ & $\begin{array}{c}\text { Forest maze, Combination table, } \\
\text { Stepping-stone net }\end{array}$ & $\begin{array}{c}\text { Combination table, Log } \\
\text { stepping-stone, Rocking swing }\end{array}$ & $\begin{array}{l}\text { Boreal digging frog habitat, } \\
\text { Spider play, Insect hotel }\end{array}$ \\
\hline
\end{tabular}

\section{Detailed status of study areas}

Table 4 shows the results of determining the detailed items of location suitability, naturality, eco-education/playfulness, and rest/community based on the 'Ecological Playground Formation Guidelines.' First, this study examined the accessibility and surrounding land use status focusing on housing, education institutions and transportation distributed within a radius of $300 \mathrm{~m}$ of the ecological playground in location suitability. As for accessibility, all study areas were adjacent to

Table 4. Detailed status of research site.

\begin{tabular}{|c|c|c|c|c|c|}
\hline & Distir & & Yangpyeong & Umyeonsan & Gulponuri \\
\hline \multirow{4}{*}{$\begin{array}{l}\text { Locational } \\
\text { suitability }\end{array}$} & \multirow{3}{*}{ Accessibility } & Education institution & $\begin{array}{l}\text { Kindergarten, } \\
\text { elementary, middle, } \\
\text { and high school }\end{array}$ & $\begin{array}{l}\text { Kindergarten, } \\
\text { elementary, middle, } \\
\text { and high school }\end{array}$ & $\begin{array}{l}\text { Elementary, middle, } \\
\text { and high school }\end{array}$ \\
\hline & & Residential area & Location to near $30 \mathrm{~m}$ & Location to near $40 \mathrm{~m}$ & Location to near $50 \mathrm{~m}$ \\
\hline & & Transportation & $\begin{array}{l}\text { No subway station in } \\
\text { a radius of } 300 \mathrm{~m}\end{array}$ & $\begin{array}{l}\text { No subway station in } \\
\text { a radius of } 300 \mathrm{~m}\end{array}$ & $\begin{array}{l}\text { Gulpocheon Station in } \\
\text { to a radius of } 240 \mathrm{~m}\end{array}$ \\
\hline & & duse status & - & Umyeonsan & Gulpocheon \\
\hline \multirow{4}{*}{ Naturality } & & een ratio & $67.9 \%$ & $65.7 \%$ & $96.6 \%$ \\
\hline & Planting & f naturalized species & $23.0 \%$ & $12.5 \%$ & $45.0 \%$ \\
\hline & Per & pavement ratio & $77.1 \%$ & $100 \%$ & $100 \%$ \\
\hline & Impe & s pavement ratio & $22.9 \%$ & - & - \\
\hline \multirow{7}{*}{$\begin{array}{l}\text { Eco-education } \\
\text { playfulness }\end{array}$} & Standarc & experience facilities & 2EA & 3EA & $8 \mathrm{EA}$ \\
\hline & Non-stand & d experience facilities & $6 \mathrm{EA}$ & 9EA & 10EA \\
\hline & Natural geomor & gy use experience facilities & - & $1 \mathrm{EA}$ & 4EA \\
\hline & Eco-frie & material playthings & $6 \mathrm{EA}$ & $8 \mathrm{EA}$ & $8 \mathrm{EA}$ \\
\hline & & nce facilities & $6 \mathrm{EA}$ & 4EA & $8 \mathrm{EA}$ \\
\hline & Educ & guidance facility & $5 \mathrm{EA}$ & 3EA & $5 \mathrm{EA}$ \\
\hline & Ecol & 1 learning space & - & $1 \mathrm{EA}$ & 4EA \\
\hline \multirow{5}{*}{$\begin{array}{l}\text { Rest } \\
\text { communities }\end{array}$} & & g space radio & $2.2 \%$ & $3.4 \%$ & $1.3 \%$ \\
\hline & \multirow{4}{*}{ Rest facilities } & Pergola & - & 2EA & $1 \mathrm{EA}$ \\
\hline & & Parasol-typed shades & - & $2 \mathrm{EA}$ & - \\
\hline & & Bench & $6 \mathrm{EA}$ & 21EA & 3EA \\
\hline & & Drinking foundation & - & $1 \mathrm{EA}$ & - \\
\hline
\end{tabular}


education institutions such as elementary, middle and high schools. Yangpyeong ecological playground and Umyeonsan ecological playground were close to a kindergarten, but Gulponuri ecological playground was not, and thus may lack efficiency in connection with education programs for preschoolers. As for land use status, Umyeonsan ecological playground in Seocho-gu was near Umyeonsan Mountain and Gulponuri ecological playground in Bupyeong-gu was near Gulpocheon eco wetlands, with location features that well reflect the characteristics of natural environment in the regions. On the other hand, Yangpyeong ecological playground was located in the city without forests, wetlands or rivers in terms of land use, thereby showing low connectivity to natural resources. Second, naturality was subdivided into green ratio, planting rate of naturalized species, pervious pavement ratio, and impervious pavement ratio. Gulponuri ecological playground showed high green ratio of $96.6 \%$, and the planting rate of naturalized species $(45.0 \%)$ was also highest. Umyeonsan ecological playground, even though it is the forest adjacent type, showed low planting rate of naturalized species (12.5\%), forming a disparate landscape.

The impervious pavement ratio of Yangpyeong ecological playground was $22.9 \%$, which suggested that it needs to be demolished due to the nature of an eco-friendly ecological playground, as it was rebuilt while maintaining the rubber chipping of the playground that had been built before. Third, eco-education/playfulness was subdivided into standardized experience facilities, non-standardized experience facilities, natural geomorphology use, eco-friendly material playground equipment, guidance facilities, distribution ratio of education guidance facility, and ecological learning space. All study areas had more non-standardized experience facilities than standardized experience facilities. For natural geomorphology use, Umyeonsan ecological playground had hill climbing using the landform of the forest, while Gulponuri ecological playground in Bupyeong-gu had water wheel using wetlands, bank slide, channel slope, and boreal digging frog habitat. Yangpyeong ecological playground was located in the city and had difficulty using ecological features nearby, and thus there were no facilities using natural topography. Eco-friendly material playground equipment was installed in 6-8 places of the three ecological playgrounds, guidance facilities in 4-8 places, and education guidance facilities in 3-5 places.

As for ecological learning space, Umyeonsan ecological playground had it in one place including a pile of rocks and mushroom growing facilities. Gulponuri ecological playground had a distribution of four ecological learning facilities such as a bird hotel, insect hotel, boreal digging frog habitat and emerged plant wetland. Fourth, to analyze rest/community, it was categorized into resting space area and rest facilities including pergolas, parasol-type shades, benches, and drinking fountains. All study areas had $4 \%$ or lower resting space ratio. Yangpyeong ecological playground did not have pergolas or parasol-type shades, and had six benches installed. Gulponuri ecological playground also had one pergola and three benches, showing the lack of rest facilities compared to the total size $\left(12,600 \mathrm{~m}^{2}\right)$. Gulponuri ecological playground is a place where many visitors bring young children to visit ecological ponds and wetlands, thereby showing high demand for rest facilities. There was one drinking fountain in Umyeonsan ecological playground and none installed in Yangpyeong and Gulponuri ecological playground.

\section{User survey status}

\section{General characteristics of users}

The general characteristics of survey participants (Table 5) show that $36.6 \%$ are men and $63.4 \%$ are women, with the ratio of female users higher than male. Most of them were in their 40s (31\%) and 30s (25.5\%).

$58.6 \%$ were university graduates, and housewives (23.4\%) took up the highest ratio for jobs, with many students and office workers as well. Children were the main users and thus $71 \%$ of survey respondents were married. As for children, most were young children, and children's age with the highest ratio was over 13 (35.5\%), followed by ages 4-6 (26.2\%) and 7-9 (18.7\%) that are kindergarten and elementary school students. 
Table 5. General information of users.

\begin{tabular}{|c|c|c|c|c|c|c|c|c|c|}
\hline \multirow{2}{*}{\multicolumn{2}{|c|}{ Distinction }} & \multicolumn{2}{|c|}{ Yangpyeong } & \multicolumn{2}{|c|}{ Umyeonsan } & \multicolumn{2}{|c|}{ Gulponuri } & \multicolumn{2}{|c|}{ All } \\
\hline & & $\begin{array}{l}\text { Frequency } \\
(\mathrm{N})\end{array}$ & $\begin{array}{l}\text { Percent } \\
(\%)\end{array}$ & $\begin{array}{l}\text { Frequency } \\
\text { (N) }\end{array}$ & $\begin{array}{c}\text { Percent } \\
(\%)\end{array}$ & $\begin{array}{l}\text { Frequency } \\
\text { (N) }\end{array}$ & $\begin{array}{l}\text { Percent } \\
(\%)\end{array}$ & $\begin{array}{l}\text { Frequency } \\
\text { (N) }\end{array}$ & $\begin{array}{c}\text { Percent } \\
(\%)\end{array}$ \\
\hline \multirow{2}{*}{ Gender } & Male & 20 & 36.4 & 20 & 50.0 & 13 & 26.0 & 53 & 36.6 \\
\hline & Female & 35 & 63.6 & 20 & 50.0 & 37 & 74.0 & 92 & 63.4 \\
\hline \multirow{7}{*}{ Age } & $10 \sim 19$ & 5 & 9.1 & - & - & 8 & 16.0 & 13 & 9.0 \\
\hline & $20 \sim 29$ & 15 & 27.3 & 2 & 5.0 & 6 & 12.0 & 23 & 15.9 \\
\hline & $30 \sim 39$ & 12 & 21.8 & 10 & 25.0 & 15 & 30.0 & 37 & 25.5 \\
\hline & $40 \sim 49$ & 13 & 23.6 & 15 & 37.5 & 17 & 34.0 & 45 & 31.0 \\
\hline & $50 \sim 59$ & 3 & 5.5 & 11 & 27.5 & - & - & 14 & 9.7 \\
\hline & $60 \sim 69$ & 5 & 9.1 & 2 & 5.0 & 1 & 2.0 & 8 & 5.5 \\
\hline & Over 70 & 2 & 3.6 & - & - & 3 & 6.0 & 5 & 3.4 \\
\hline \multirow{5}{*}{ Education } & Middle school & 4 & 7.3 & - & - & 8 & 16.0 & 12 & 8.3 \\
\hline & High school & 13 & 23.6 & 8 & 20.0 & 10 & 20.0 & 31 & 21.4 \\
\hline & Community college & 2 & 3.6 & 5 & 12.5 & 7 & 14.0 & 14 & 9.7 \\
\hline & Undergraduate & 35 & 63.6 & 25 & 62.5 & 25 & 50.0 & 85 & 58.6 \\
\hline & Graduate & 1 & 1.8 & 2 & 5.0 & - & - & 3 & 2.1 \\
\hline \multirow{9}{*}{ Job } & Office worker & 5 & 9.1 & 7 & 17.5 & 8 & 16.0 & 20 & 13.8 \\
\hline & Official & 6 & 10.9 & - & - & 2 & 4.0 & 8 & 5.5 \\
\hline & Technician & 5 & 9.1 & 3 & 7.5 & 3 & 6.0 & 11 & 7.6 \\
\hline & Student & 13 & 23.6 & 2 & 5.0 & 14 & 28.0 & 29 & 20.0 \\
\hline & Self-employment & 5 & 9.1 & 10 & 25.0 & 4 & 8.0 & 19 & 13.1 \\
\hline & Housewife & 10 & 18.2 & 14 & 35.0 & 10 & 20.0 & 34 & 23.4 \\
\hline & Service & 9 & 16.4 & 2 & 5.0 & 1 & 2.0 & 12 & 8.3 \\
\hline & No job & 2 & 3.6 & 1 & 2.5 & 4 & 8.0 & 7 & 4.8 \\
\hline & Other & - & - & 1 & 2.5 & 4 & 8.0 & 5 & 3.4 \\
\hline \multirow{3}{*}{$\begin{array}{l}\text { Marital } \\
\text { Status }\end{array}$} & Single & 20 & 36.4 & 7 & 17.5 & 14 & 28.0 & 41 & 28.3 \\
\hline & Married & 35 & 63.6 & 33 & 82.5 & 35 & 70.0 & 103 & 71.0 \\
\hline & Other & - & - & - & - & 1 & 2.0 & 1 & 0.7 \\
\hline \multirow{2}{*}{$\begin{array}{l}\text { Presence of } \\
\text { Minor child }\end{array}$} & Yes & 23 & 65.7 & 25 & 69.4 & 29 & 78.4 & 77 & 71.3 \\
\hline & No & 12 & 34.3 & 11 & 30.6 & 8 & 21.6 & 31 & 28.7 \\
\hline \multirow{5}{*}{$\begin{array}{l}\text { Child } \\
\text { Age }\end{array}$} & $1 \sim 3$ & 3 & 8.6 & 2 & 5.7 & 1 & 2.7 & 6 & 5.6 \\
\hline & $4 \sim 6$ & 8 & 22.9 & 9 & 25.7 & 11 & 29.7 & 28 & 26.2 \\
\hline & $7 \sim 9$ & 5 & 14.3 & 6 & 17.1 & 9 & 24.3 & 20 & 18.7 \\
\hline & $10 \sim 12$ & 5 & 14.3 & 5 & 14.3 & 5 & 13.5 & 15 & 14.0 \\
\hline & Over 13 & 14 & 40.0 & 13 & 37.1 & 11 & 29.7 & 38 & 35.5 \\
\hline
\end{tabular}

\section{User behavior}

Awareness, number of use, use time, purpose of use and accompanying person were examined to determine the user behavior of ecological playgrounds (Table 6). As a result of surveying users' awareness of ecological playgrounds, $61.4 \%$ 
Table 6. Use behavior of research site.

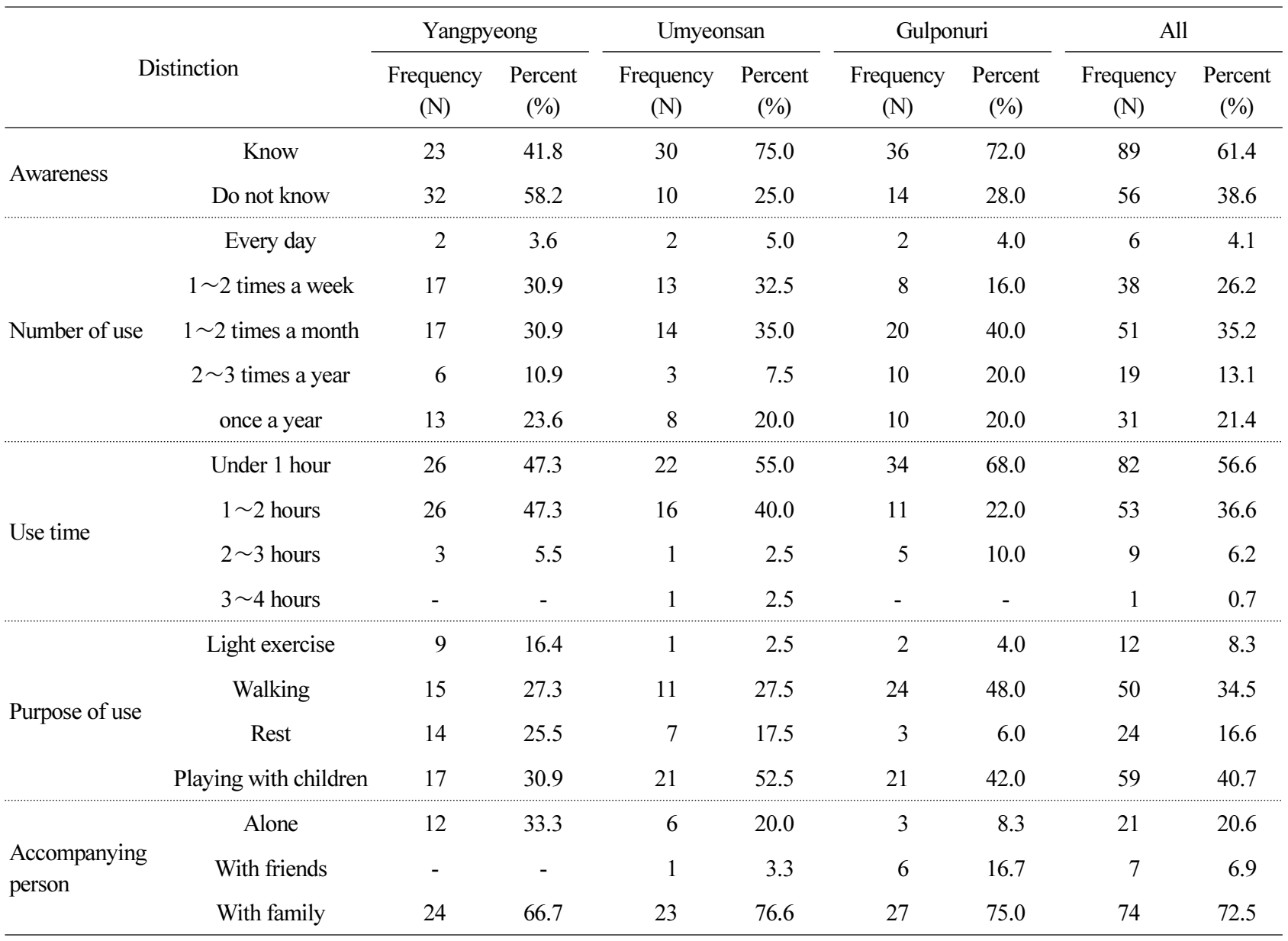

were aware of and using ecological playgrounds. Most of them used it 1-2 times a month (35.2\%), followed by 1-2 times a week (26.2\%).

The average time they used the playgrounds was less than 1 hour $(56.6 \%)$ or within 1-2 hours $(36.6 \%)$, and the main purpose of use was playing with children (40.7\%) or taking a walk (34.5\%). Most of them used the playgrounds with family (72.5\%).

\section{User satisfaction}

(1) Satisfaction with composition of ecological playgrounds

This study examined the mean difference of satisfaction with composition of each factor of the study areas by users of ecological playgrounds (Table 7). More specifically, it was classified into usage effect, accessibility, walkway availability, natural perception, and kind of tree. As a result of comparing satisfaction, it was found that there was not much of a difference among all items. In terms of usage effect and accessibility, the mean of the three study areas was 3.40 and 3.57, which were higher than average. As for walkway availability, the mean was 3.46 (3.35-3.58), with Gulponuri ecological playground slightly higher than average. Natural perception was 3.53-3.66 (mean 3.61), slightly high in Umyeonsan ecological playground (3.65) near a forest and Gulponuri ecological playground (3.66) near a river.

As for kind of tree, the result was similar to natural perception with the mean of 3.52, with Umyeonsan ecological playground (3.55) slightly higher than average. 
Table 7. One-way ANOVA result on satisfaction of composition factor by users.

\begin{tabular}{|c|c|c|c|c|}
\hline Distinction & Group & Mean & $\mathrm{F}$ & P-value \\
\hline & Umyeonsan & 3.38 & & \\
\hline \multirow[t]{3}{*}{ Usage effect } & Yangpyeong & 3.47 & 0.319 & 0.727 \\
\hline & Gulponuri & 3.36 & & \\
\hline & Umyeonsan & 3.60 & & \\
\hline \multirow[t]{3}{*}{ Accessibility } & Yangpyeong & 3.49 & 0.419 & 0.659 \\
\hline & Gulponuri & 3.62 & & \\
\hline & Umyeonsan & 3.35 & & \\
\hline \multirow[t]{3}{*}{ Walkway availability } & Yangpyeong & 3.45 & 0.953 & 0.388 \\
\hline & Gulponuri & 3.58 & & \\
\hline & Umyeonsan & 3.65 & & \\
\hline \multirow[t]{3}{*}{ Natural perception } & Yangpyeong & 3.53 & 0.625 & 0.537 \\
\hline & Gulponuri & 3.66 & & \\
\hline & Umyeonsan & 3.55 & & \\
\hline \multirow[t]{2}{*}{ Kind of tree } & Yangpyeong & 3.51 & 0.042 & 0.959 \\
\hline & Gulponuri & 3.52 & & \\
\hline
\end{tabular}

$* * p<.01$

(2) Satisfaction with facilities of ecological playgrounds

As a result of analyzing the mean difference of study areas regarding satisfaction with facilities of ecological playgrounds (Table 8), it was found that floor pavement was 3.20-3.34 (mean 3.27) in the three areas, with Gulponuri

Table 8. One-way ANOVA result on satisfaction of facility factor by users.

\begin{tabular}{|c|c|c|c|c|}
\hline Distinction & Group & Mean & $\mathrm{F}$ & P-value \\
\hline \multirow{3}{*}{ Floor pavement } & Umyeonsan & 3.20 & \multirow{3}{*}{0.358} & \multirow{3}{*}{0.700} \\
\hline & Yangpyeong & 3.27 & & \\
\hline & Gulponuri & 3.34 & & \\
\hline \multirow{3}{*}{ Safety facilities } & Umyeonsan & 3.20 & \multirow{3}{*}{2.983} & \multirow{3}{*}{0.054} \\
\hline & Yangpyeong & 3.20 & & \\
\hline & Gulponuri & 2.82 & & \\
\hline \multirow{3}{*}{$\begin{array}{l}\text { Etc facilities } \\
\text { (Toilet, drinking fountain, trash can) }\end{array}$} & Umyeonsan & 2.98 & \multirow{3}{*}{1.634} & \multirow{3}{*}{0.199} \\
\hline & Yangpyeong & 2.69 & & \\
\hline & Gulponuri & 2.58 & & \\
\hline \multirow{3}{*}{$\begin{array}{l}\text { Information facilities } \\
\text { (Information board, plants label) }\end{array}$} & Umyeonsan & 3.25 & \multirow{3}{*}{2.684} & \multirow{3}{*}{0.072} \\
\hline & Yangpyeong & 3.47 & & \\
\hline & Gulponuri & 3.12 & & \\
\hline \multirow{3}{*}{$\begin{array}{l}\text { Rest facilities } \\
\text { (Pergola, bench) }\end{array}$} & Umyeonsan & 2.83 & \multirow{3}{*}{5.811} & \multirow{3}{*}{$0.004^{* *}$} \\
\hline & Yangpyeong & 3.38 & & \\
\hline & Gulponuri & 2.86 & & \\
\hline
\end{tabular}

$* * p<.01$ 
ecological playground (3.34) higher than average. The mean was 3.07 for safety facilities, with Gulponuri ecological playground (2.82) lower than average. This result may be due to the concern for negligent accidents caused by carelessness of children, as there are no safety handrails on the observation deck of the wetlands. As for rest facilities including pergolas and benches, Umyeonsan ecological playground (2.83) and Gulponuri ecological playground (2.86) were lower than average (3.02). This is due to the lack of rest facilities for parents that are guardians of the children in terms of rest/community.

\section{User preference}

(1) Programs using five senses

To examine the preference of ecological experience and education programs of ecological playgrounds, this study categorized the programs into five senses such as sight, hearing, smell, taste and touch. Accordingly, ecological experience and education programs were set up to determine the preference, such as observing sprouts/flowers/maple/ trees, observing bugs, and observing wild animals for sight; listening to the sound of the forest, listening to the sound of the stream, and listening to the sound of bugs/animals for hearing; smelling flowers, smelling trees, and smelling fruits for smell; tasting edible plants, tasting fruits, and tasting honey for taste; and touching trees, collecting bugs, and walking barefoot for touch.

To determine the preference of ecological experience and education programs of ecological playgrounds, a preference survey was conducted on 15 programs using five senses (Table 9), and the result showed that the preference was highest for sight (33.5\%), followed by hearing (29.6\%) and smell (25.1\%). The factors that took up the highest ratio for each type were observing the forest (17.2\%) for sight, listening to the sound of the forest (11.7\%) for hearing, and smelling flowers

Table 9. Preference result of program factor by users

\begin{tabular}{|c|c|c|c|c|c|c|c|c|c|}
\hline & \multirow[b]{2}{*}{ Distinction } & \multicolumn{2}{|c|}{ Yangpyeong } & \multicolumn{2}{|c|}{ Umyeonsan } & \multicolumn{2}{|c|}{ Gulponuri } & \multicolumn{2}{|c|}{ All } \\
\hline & & $\begin{array}{l}\text { Frequency } \\
\text { (N) }\end{array}$ & $\begin{array}{c}\text { Percent } \\
(\%)\end{array}$ & $\begin{array}{l}\text { Frequency } \\
\text { (N) }\end{array}$ & $\begin{array}{c}\text { Percent } \\
(\%)\end{array}$ & $\begin{array}{l}\text { Frequency } \\
\text { (N) }\end{array}$ & $\begin{array}{c}\text { Percent } \\
(\%)\end{array}$ & $\begin{array}{l}\text { Frequency } \\
\text { (N) }\end{array}$ & $\begin{array}{c}\text { Percent } \\
(\%)\end{array}$ \\
\hline & 1) Observation of the forest & 37 & 22.4 & 16 & 13.3 & 22 & 14.7 & 75 & 17.2 \\
\hline \multirow[t]{3}{*}{ Sight } & 2) Observation of bugs & 11 & 6.7 & 10 & 8.3 & 16 & 10.7 & 37 & 8.5 \\
\hline & 3) Observation of wild animals & 11 & 6.7 & 10 & 8.3 & 13 & 8.7 & 34 & 7.8 \\
\hline & 4) Sound of the forest & 16 & 9.7 & 14 & 11.7 & 21 & 14.0 & 51 & 11.7 \\
\hline \multirow[t]{3}{*}{ Hearing } & 5) Sound of the stream & 22 & 13.3 & 9 & 7.5 & 9 & 6.0 & 40 & 9.2 \\
\hline & 6) Sound of bugs/animals & 12 & 7.3 & 8 & 6.7 & 18 & 12.0 & 38 & 8.7 \\
\hline & 7) Smell of flowers & 16 & 9.7 & 14 & 11.7 & 33 & 22.0 & 63 & 14.5 \\
\hline \multirow[t]{3}{*}{ Smell } & 8) Smell of trees & 13 & 7.9 & 4 & 3.3 & 13 & 8.7 & 30 & 6.9 \\
\hline & 9) Smell of fruits & 8 & 4.8 & 4 & 3.3 & 4 & 2.7 & 16 & 3.7 \\
\hline & 10) Edible plants & 1 & 0.6 & 2 & 1.7 & - & - & 3 & 0.7 \\
\hline \multirow[t]{3}{*}{ Taste } & 11) Fruits taste & 3 & 1.8 & 2 & 1.7 & - & - & 5 & 1.1 \\
\hline & 12) Honey taste & 1 & 0.6 & - & - & - & - & 1 & 0.2 \\
\hline & 13) Touching trees & 5 & 3.0 & 7 & 5.8 & - & - & 12 & 2.8 \\
\hline \multirow[t]{2}{*}{ Touch } & 14) Collecting bugs & 6 & 3.6 & 8 & 6.7 & 1 & 0.7 & 15 & 3.4 \\
\hline & 15) Walking barefoot & 3 & 1.8 & 12 & 10.0 & - & - & 15 & 3.4 \\
\hline
\end{tabular}


(14.5\%) for smell. More specifically, Yangpyeong ecological playground had highest preference in sight (35.8\%), followed by hearing (30.3\%) and smell (22.4\%). Umyeonsan ecological playground had highest preference in sight (29.9\%), followed by hearing $(25.9 \%)$ and touch $(22.5 \%)$. Gulponuri ecological playground had highest preference in sight (34.1\%), followed by smell (33.4\%) and hearing (32.0\%). Among the five senses, sight showed highest preference in all ecological playgrounds, and for subdivided ecological experience and education programs, the mean of preference in observation of forest (17.2\%) was highest. Taste showed lowest preference in all ecological playgrounds, and tasting honey $(0.2 \%)$ showed the lowest mean. Preference in detailed ecological experience and education programs in Yangpyeong ecological playground was highest in observing the forest (22.4\%) for sight, followed by listening to the sound of the stream (13.3\%) and the forest $(9.7 \%)$ for hearing, and smelling flowers $(9.7 \%)$ for smell. In Umyeonsan ecological playground, preference was highest in observing the forest (13.3\%) for sight, followed by listening to the sound of the forest (11.7\%), for hearing, and smelling flowers (11.7\%) for smell. In Gulponuri ecological playground, preference was highest in smelling flowers $(22.0 \%)$ for smell, followed by observing the forest (14.7\%) for sight, and listening to the sound of the forest (14.0\%) for hearing. Accordingly, rather than planning programs using taste that will end up in low participation rates due to low preference, it seems more desirable to come up with programs focused on herbal plants to observe sprouts/flowers/maple/trees in the forest for sight; listen to the sound of stepping on fallen leaves, the sound of leaves flying and the sound of the stream for hearing; and finding out the differences in the smell of flowers for smell. By doing so, it would be able to promote positive effects of ecological experience and learning and vitalize ecological playgrounds.

(2) Major facilities and spaces

To examine preference of facilities in ecological playgrounds, this study investigated the preference by classifying into improvement/addition of playground equipment, pergolas, benches, and lighting, thereby determining the mean difference among study areas. The mean difference of the preference of additional facilities showed a significant result in improvement/addition of playground equipment, pergolas and benches (Table 10). More specifically, additional preference of playground equipment, pergolas and benches was 3.31-3.63, showing higher preference than average. Gulponuri ecological playground showed higher preference for playground equipment (3.60), pergolas (3.94), and benches (3.92) than the other two ecological playgrounds. Gulponuri ecological playground had $1.3 \%$ of rest area, one pergola and three benches installed in the process of emphasizing the features of an ecological playground differentiated from an ordinary playground, thereby showing high demand for the lack of basic rest facilities. Since there is a need for rest areas for guardians accompanying young children (rest/community), it is necessary to meet the user needs for rest functions by additionally installing and supplementing pergolas and benches. For preference of major space, this study investigated the preference of rest area and experience and learning space such as a visitor's center where there is eco-education and experience as well as guidance, and determined the mean difference among study areas (Table 10). Preference of major spaces showed a significant result in rest area and experience and learning space for all study areas. Preference for rest area had the mean of 3.43, and the demand (3.70) was slightly high in Gulponuri ecological playground. Preference for experience and learning space had the mean of 3.68, showing a generally high demand, which was especially high (4.00) in Gulponuri ecological playground where there are many ecological spaces and education facilities such as wetlands, boreal digging frog habitats, bird hotel and insect hotel. This is because users feel the most need for a visitor's information center and experience and learning space to receive ecological information, education, experience and guidance, as the playground has a big area and has the advantage of specializing eco-education and play in connection with ecological ponds and wetlands. 
Table 10. One way ANOVA result on the necessity for improvement of facility and space.

\begin{tabular}{|c|c|c|c|c|}
\hline Distinction & Group & Mean & $\mathrm{F}$ & P-value \\
\hline & Umyeonsan & 3.18 & & \\
\hline \multirow[t]{3}{*}{ Rides } & Yangpyeong & 3.15 & 5.265 & $0.006^{* *}$ \\
\hline & Gulponuri & 3.60 & & \\
\hline & Umyeonsan & 3.50 & & \\
\hline \multirow[t]{3}{*}{ Pergola } & Yangpyeong & 3.45 & 7.438 & $0.001 * *$ \\
\hline & Gulponuri & 3.94 & & \\
\hline & Umyeonsan & 3.58 & & \\
\hline \multirow[t]{3}{*}{ Bench } & Yangpyeong & 3.40 & 6.369 & $0.002 * *$ \\
\hline & Gulponuri & 3.92 & & \\
\hline & Umyeonsan & 3.40 & & \\
\hline \multirow[t]{3}{*}{ Lighting } & Yangpyeong & 3.45 & 0.588 & 0.557 \\
\hline & Gulponuri & 3.56 & & \\
\hline & Umyeonsan & 3.20 & & \\
\hline \multirow[t]{3}{*}{ Rest space } & Yangpyeong & 3.38 & 5.217 & $0.007 * *$ \\
\hline & Gulponuri & 3.70 & & \\
\hline & Umyeonsan & 3.38 & & \\
\hline \multirow[t]{2}{*}{ Experience learning space } & Yangpyeong & 3.65 & 8.063 & $0.000 * *$ \\
\hline & Gulponuri & 4.00 & & \\
\hline
\end{tabular}

$* * p<.01$

\section{Conclusion}

This study examined the current status of ecological playgrounds by type that have been built since 2014 until today and conducted a preference and satisfaction survey of users, thereby presenting baseline data for plans to promote and vitalize ecological playgrounds. The study areas were Yangpyeong ecological playground in Yeongdeungpo-gu in the urban life type, Umyeonsan ecological playground in Seocho-gu in the forest adjacent type, and Gulponuri ecological playground in Bupyeong-gu in the waterside type.

As a result of examining the current status, it is necessary to reinforce the connectivity between the characteristics of natural resources and ecological resources at the ecological playgrounds in terms of location suitability. Umyeonsan ecological playground in Seocho-gu was near Umyeonsan Mountain and Gulponuri ecological playground in Bupyeong-gu was near Gulpocheon eco wetlands, with location features that well reflect the characteristics of natural environment. However, Yangpyeong ecological playground was located in the city with low connectivity to natural resources. Thus, it is necessary to implement biospecies that can live in the city and actively build small biospheres of small animals. As for naturality, Gulponuri ecological playground had high green ratio and planting rate of naturalized species. On the other hand, Umyeonsan ecological playground, even though it is a forest adjacent type, had low planting rate of naturalized species and thus a disparate environment. It is necessary to secure connectivity with surrounding forest environment and build an environment focused on native tree species where other biospecies can enter. When it comes to impervious 
pavement ratio, Yangpyeong ecological playground maintained the rubber chipping that had been built before, which lowered the ecological property of the playground. Thus, it is necessary to come up with a plan to minimize impervious pavement. For eco-education/playfulness, there were more non-standardized experience facilities than standardized experience facilities (ready-made) in all study areas, which coincided more with ecological property. As for natural geomorphology use, Umyeonsan ecological playground had hill climbing using the landform of the forest, while Gulponuri ecological playground in Bupyeong-gu had water wheel using wetlands, bank slide, channel slope, and boreal digging frog habitat. Yangpyeong ecological playground was located in the city and had difficulty using ecological features nearby, and thus there were no facilities using natural topography. Various age groups like babies, children, teenagers and accompanying guardians use ecological playgrounds. Thus, it is necessary for them to function as a rest/community space by improving facilities for not only experience and play but also rest and convenience.

Satisfaction with composition of ecological playgrounds turned out to be above average overall, indicating positive use. As for satisfaction with facilities, there was low satisfaction for rest facilities (pergolas, benches), toilets, and subsidiary facilities, including drinking fountains and trash cans. This implies that it is necessary to reflect the need for facilities as a rest/community space for user convenience along with the purpose of building an ecological playground.

In preference of programs using five senses, the average preference was lowest in ecological experience and education programs using taste, while the preference was high in observing sprouts/flowers/maple/trees in the forest for sight; listening to the sound of stepping on fallen leaves, the sound of leaves flying, the sound of the forest and the sound of the stream for hearing; and finding out the differences in the smell of flowers for smell. Kim (2016a) also emphasized the need for active reflection of eco-friendly elements, connection with natural resources considering surrounding topography, water vein and gate, and programs using five senses focused on sight and hearing when plans for ecological playgrounds are made. In other words, there was high demand for forest experiences using natural resources around the study areas, complex learning and experience programs of five senses using streams and wetlands.

As for preference of major facilities and spaces, the demand for pergolas and benches was highest like the satisfaction with facilities, and preference of eco-education facilities and experience and learning space with signboards was highest. This suggests that since expectations are high for eco-education when visiting ecological playgrounds, it is necessary to provide information on the ecological resources of the area, install small information centers for understanding and learning of ecological spaces, set up detailed signboards about the characteristics of each ecological space, and plan programs linked to various experiences and learning elements. As proposed by Park (2016), ecological playgrounds can perform their role and seek constant vitalization by implementing local volunteer program for nature interpretation and supporting programs categorized into direct operation and participatory operation in cooperation with education institutions and local governments.

\section{References}

Bang, S.H. and S.W. Lee. 2008. Effects on environmental attitudes of elementary school students through site-based environmental education using ecological park. J. Korean Soc. Elementary Educ. 19(1):57-75.

Cho, H.K. 2011. Study on educational programs in ecological park and its application for secondary education. MS thesis, Konkuk Univ., Seoul, Korea.

Kang, M.H. 2011. A case study on forest kindergarten. -Experiencing forest activity in Yourim kindergarten. MS thesis, Kangnam Univ., Yongin, Korea.

Kim, J.K. 2016a. A study on the planning properties of ecological playground through case studies. J. Korean Inst. Int. Des. 25(2):70-82. DOI:10.14774/JKIID.2016.25.2.070 
Kim, N.C. 2016b. The present condition and activation plan of nature conservation and restoration works: Special Issue commemorating volume 100 of Journal of The Korea Society of Environmental Restoration Technology. J. Korean Soc. of Environ. Restora. Tech. 19(3):123-132.

Kim, Y. 2010. Impact on the child's creativity of free play in the Korea's first forest kindergarten. -Case of Incheon University forest kindergarten. MS thesis, Incheon Univ., Incheon, Korea.

Ku, M.S. 2011. Development plan for the ecological park of a reservoir in suburban area. -A case study of Maeji reservoir, Wonju, Korea. MS thesis, Korea Univ. of Seoul, Seoul, Korea.

Lee, M.S. 2008. An urban ecological park design study with the application of the theory of landscape ecology. -A case study of Namyangju Jinjeop, Gyeonggi, Korea. MS thesis, Hanyang Univ., Seoul, Korea.

Lee, S.J. 2010. Case study on forest-kindergartens. MS thesis, Korea Univ., Seoul, Korea.

Ministry of Environment. 2014a. Ecological playground guidelines. Seoul, Korea.

Ministry of Environment. 2014b. Composition model guidebook by type ecological playground "The child a yard". Seoul, Korea.

Park, H.S. 2016. Design and management of eco-playpark. -Focused on operation program. MS thesis, Dankook Univ., Cheonan, Korea.

Park, S.K. 2004. A study on classification and its criteria of facility programmed for urban ecology park. MS thesis, Kyungwon Univ., Seongnam, Korea. 